\title{
$\mathrm{Au}$ 와 탄소나노튜브 복합체 전극의 연성 향상
}

\author{
우정민 · 전주희 · 강지연 · 이태일 · 명재민 ${ }^{\dagger}$ \\ 연세대학교 신소재공학부
}

\section{Enhanced Stretchability of Gold and Carbon Nanotube Composite Electrodes}

\author{
Jungmin Woo, Joohee Jeon, Jiyeon Kang, Tae Il Lee and Jae-Min Myoung ${ }^{\dagger}$ \\ Information and Electronic Materials Research Laboratory, Department of Materials Science and \\ Engineering, Yonsei University
}

(2010년 12월 23일 접수 : 2011년 1월 10일 최종수정 : 2011년 1월 10일 채택)

\begin{abstract}
Gold have been used as an electrode materials having a good mechanical flexibility as well as electrical conductivity, however the stretchability of the gold on a flexible substrate is poor because of its small elastic modulus. To overcome this mechanical inferiority, the reinforcing gold is necessary for the stretchable electronics. Among the reinforcing materials having a large elastic modulus, carbon nanotube (CNT) is the best candidate due to its good electrical conductivity and nanoscale diameter. Therefore, similarly to ferroconcrete technology, here we demonstrated gold electrodes mechanically reinforced by inserting fabrics of CNTs into their bodies. Flexibility and stretchability of the electrodes were determined for various densities of CNT fabrics. The roles of CNTs in resisting electrical disconnection of gold electrodes from the mechanical stress were confirmed using field emission scanning electron microscope and optical microscope. The best mechanical stability was achieved at a density of CNT fabrics manufactured by $1.5 \mathrm{ml}$ spraying. The concept of the mechanical reinforced metal electrode by CNT is the first trial for the high stretchable conductive materials, and can be applied as electrodes materials in various flexible and stretchable electronic devices such as transistor, diode, sensor and solar cell and so on.
\end{abstract}

Key words stretchable, gold, flexible, CNT, composite.

\section{1. 서 론}

차세대 디스플레이는 언제 어디서나 정보를 얻을 수 있 는 가볍고 휴대 가능하며, 다양한 표면에 적용 가능한 형 태로 발전할 것으로 예상된다. 이러한 조건을 만족 시키 기 위해서는 유연하며, 연성이 있는 기판에서 구동이 가 능한 전극이 필요하며, 이러한 전극은 디스플레이뿐만 아 니라 센서, 태양전지 등의 다양한 소자에 적용하기 위한 연구가 이루어지고 있다. ${ }^{1-4)}$ 특히 신호를 전달하는 전극의 경우 높은 속도의 소자 구현을 위해 연성을 가지는 동시 에 뛰어난 전기적 특성을 가져야 한다. 하지만, 금속 전 극의 경우 낮은 물리적 strain에도 쉽게 전도성을 잃는 특 성을 가지고 있다. ${ }^{5}$ 이를 위해 입자 형태로 금속 전극을 제작하거나 전극의 구조를 변형하는 연구가 진행 되어 왔 으며, 최근 탄소나노튜브와 그래핀, 그리고 전도성 고분 자 등의 대체 물질을 통한 연성 전극 구현이 이루어지고

${ }^{\dagger}$ Corresponding author

E-Mail : jmmyoung@yonsei.ac.kr (J. -M. Myoung)
있다. ${ }^{6-9)}$

이런 대체 물질 중 탄소나노튜브는 한 겹의 흑연이 관 형태로 말린 모양으로, 뛰어난 전기적 특성과 광학적 특 성, 그리고 높은 기계적 강도와 탄성을 가지고 있어, 투명 전극, 배터리, 방열소재 및 보강제로 사용되고 있다. ${ }^{10-12)}$ 하 지만, 탄소나노튜브 간의 van der Waals 인력은 bundle을 형성하며, 이러한 분산의 불안정성은 탄소나노튜브 전극의 전기적 특성을 저해하는 요소가 된다. ${ }^{13)}$ 그러므로 기존에 사용하고 있는 금속을 사용하면서 crack을 방지할 수 있 는 새로운 소재의 개발이 필요하다.

본 연구에서는 전도도가 뛰어난 $\mathrm{Au}$ 전극에 탄소나노튜 브를 보강제로 사용하여 전극의 연성 정도를 향상 시키는 연구를 진행하였다. 탄소나노튜브는 $\mathrm{Au}$ 전극 사이에 삽입 되어 샌드위치 구조로 제작 되었다. 사용된 탄소나노튜브 는 spray coating 방식으로 $\mathrm{Au}$ 전극 위에 증착하였으며, 삽입되는 탄소나노튜브의 양을 조절하여 tensile strain과 기 판의 곡률 변화에 따른 전기적 특성의 변화를 관찰하였으 며, 이를 통하여 제작된 전극의 연성 디스플레이 적용가 능성을 평가하였다. 


\section{2. 실험 방법}

본 실험에서는 투명하면서 연성의 성질을 가지는 고분 자 물질인polydimethylsiloxane (PDMS)을 기판으로 사용하 였다. PDMS는 Sylgard Silicone Elastomer 184와 Sylgard Curing Agent 184를 10:1 비율로 섞은 뒤 $6 \mathrm{~mm}$ 의 두께 로 제작하였다. 합성한 $\mathrm{PDMS}$ 는 상온에서 기포를 제거한 뒤, $80^{\circ} \mathrm{C}$ 온도에서 4 시간 동안 열을 가해주어 경화시켰다.

실험에 사용된 탄소나노튜브는 아크 방전 공정으로 합 성한 두께 $2 \mathrm{~nm}$ 의 단층벽 탄소나노튜브(SWCNT) (Nanosolution Co. Ltd., SA-210)이다. 합성된 탄소나노튜브는 초음파 분사기를 이용하여 분산제 sodium dodecyl sulfate (SDS)와 1:1 비율로 물에 30 분 동안 분산하였다. 분산된 용액은 원심분리기를 이용하여 $10,000 \mathrm{G}$ 에서 20 분 동안 분리를 하여 용액을 제조하였다.

제작된 PDMS 기판 위에 금속 마스크를 사용하여 선 형태로 전극을 형성하였다. Au 전극은 thermal evaporator 를 이용하여 제작하였으며, 증착 속도는 평균 $4 \AA / s$ 를 유 지하였다. 먼저 $100 \mathrm{~nm}$ 두께의 $\mathrm{Au}$ 전극을 증착한 뒤, 준 비한 탄소나노튜브 용액을 spray coating 방식을 이용하여 증착하였다. 탄소나노튜브 밀도에 따른 전극 특성 변화를
관찰하기 위하여 탄소나노튜브가 들어가지 않은 전극과 0.13 와 $0.38 \mathrm{~mL} / \mathrm{cm}^{2}$ 의 양이 증착된 전극으로 나누어 제작 하였다. 탄소나노튜브는 증착 뒤에 전기적 절연성을 가지 고 있는 분산제 $\mathrm{SDS}$ 를 물로 씻어 제거하였다. 마지막으 로 다시 한번 $\mathrm{Au}$ 를 위와 동일한 방법으로 $100 \mathrm{~nm}$ 두께 로 증착하여 $\mathrm{Au}$ 전극 사이에 탄소나노튜브 층이 삽입된 구조로 전극을 제작하였다. 전극의 유연성 시험은 기판의 곡률 반경을 9.5, 5.8 그리고 $3.4 \mathrm{~mm}$ 로 변형시키면서 측 정하였으며, 연성 시험은 tensile strain을 $0 \%$ $40 \%$ 까지 $10 \%$ 간격으로 늘여주면서 전극의 $\mathrm{I}-\mathrm{V}$ 를 측정하여 변화를 관찰하였다.

본 연구에서 전극의 표면과 탄소나노튜브의 농도는 field emission scanning electron microscope (FESEM)을 이용하 여 관찰하였으며, 전극의 균열 정도는 광학 현미경을 통해 분석하였다. 전극의 전기적 특성은 semiconductor parameter analyzer (HP-4145B)를 이용하여 측정하였다.

\section{3. 결과 및 고찰}

Fig. 1(a)는 본 실험에서 제작한 전극의 개략도이다. 연 성을 가지는 PDMS 기판 위에 형성된 $\mathrm{Au}$ 와 탄소나노튜
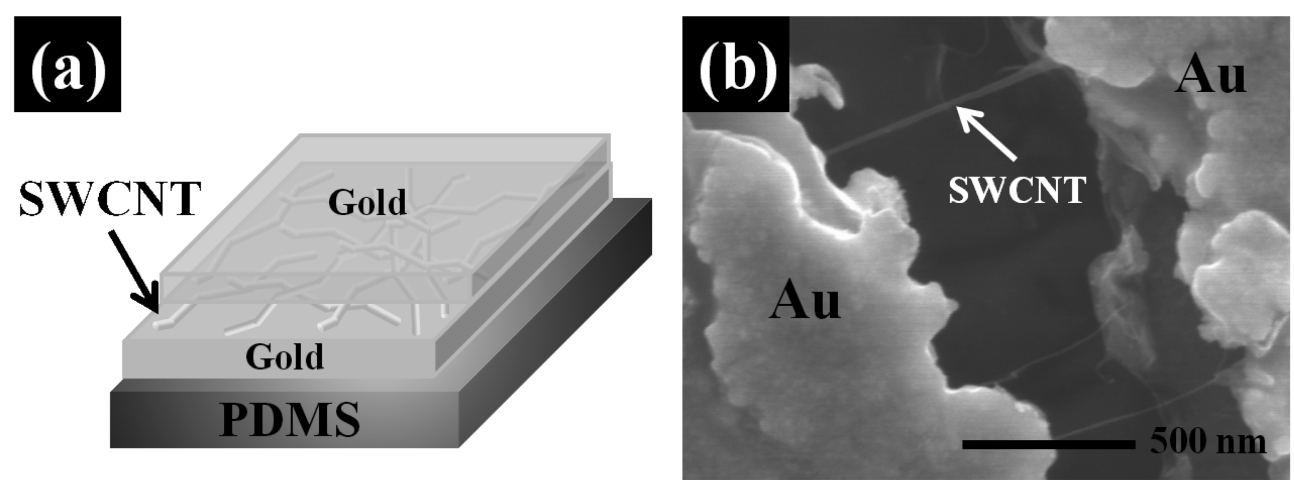

Fig. 1. (a) Schematic illustration of the Au-SWCNT composite electrode. (b) FESEM images of the Au-SWCNT composite electrode while $10 \%$ tensile strain was applied.
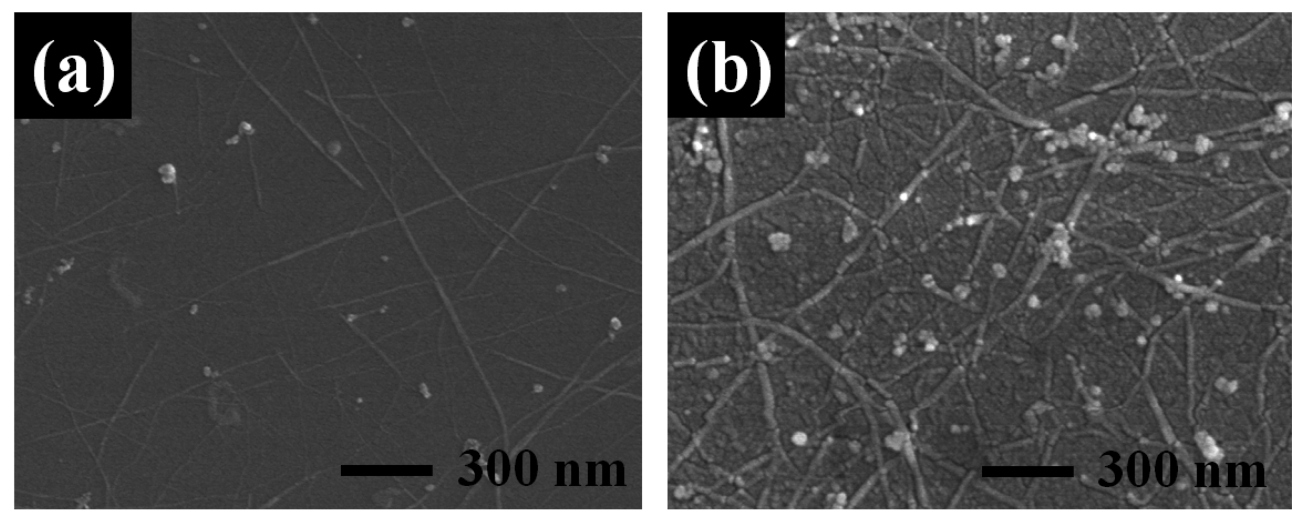

Fig. 2. The FESEM images of SWCNT films deposited at (a) $0.13 \mathrm{~mL} / \mathrm{cm}^{2}$ and (b) $0.38 \mathrm{~mL} / \mathrm{cm}^{2}$. 

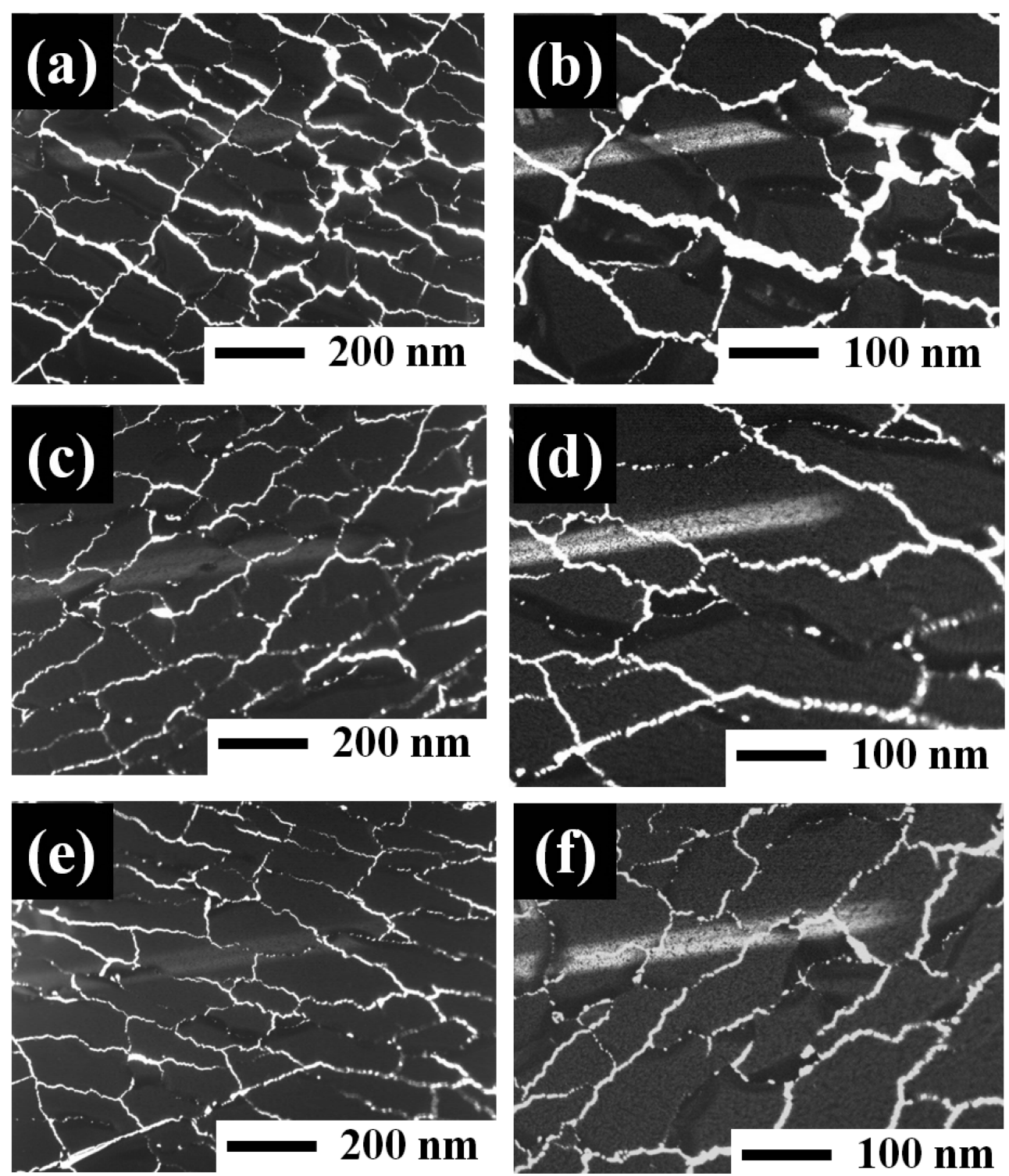

Fig. 3. Optical microscopy images of Au-SWCNT composite electrodes observed at different magnifications; (a), (b) without SWCNT, (c), (d) $0.13 \mathrm{~mL} / \mathrm{cm}^{2}$ and (e), (f) $0.38 \mathrm{~mL} / \mathrm{cm}^{2}$ of SWCNT inserted.

브 복합체 전극은 탄소나노튜브가 두 층의 $\mathrm{Au}$ 전극 (각 $100 \mathrm{~nm}$ )에 삽입된 형태로 제작 되었다. Fig. 1(b)는 $10 \%$ 의 tensile strain을 전극에 가해주었을 때 FESEM 사진이 다. FESEM 사진을 통해서 금속 전극 사이에 균열이 생 기는 것을 확인하였다. 또한, 금속 전극 사이에 삽입 되 어있던 탄소나노튜브 bundle이 물리적 strain이 가해 질 때 늘어나면서 균열된 전극을 연결해 주고 있는 것을 확인 하였다. 본 실험에서는 탄소나노튜브의 밀도가 전극의 전 기적 특성에 미치는 영향을 관찰하기 위하여 두 가지 다 른 농도의 탄소나노튜브를 $\mathrm{Au}$ 전극 사이에 삽입하였다. Fig. 2는 spray coating 방식으로 탄소나노튜브를 (a) 0.13 $\mathrm{mL} / \mathrm{cm}^{2}$ 와 (b) $0.38 \mathrm{~mL} / \mathrm{cm}^{2}$ 의 양으로 증착한 박막의 FESEM 사진이다. 탄소나노튜브의 양이 증가하면서 탄소나노튜브
네트워크의 밀도가 높아진 것을 확인 할 수 있었다.

Fig. 3은 $\mathrm{Au}$ 전극에 탄소나노튜브를 삽입하여 전극 복 합체를 제조한 뒤, $10 \%$ 의 tensile strain이 가해 졌을 때 전극 표면을 광학 현미경으로 다른 배율에서 관찰한 사진 이다. Fig. 3(a)와(b)는 탄소나노튜브를 삽입하지 않은 $\mathrm{Au}$ 전극(두께 : $200 \mathrm{~nm}$ )의 표면이며 (c)와 (d)는 $0.13 \mathrm{~mL} / \mathrm{cm}^{2}$ 그 리고 (e)와 $(\mathrm{f})$ 는 $0.38 \mathrm{~mL} / \mathrm{cm}^{2}$ 의 탄소나노튜브를 삽입한 전 극 표면이다. 탄소나노튜브를 전혀 넣어주지 않은 전극의 경우 $0.13 \mathrm{~mL} / \mathrm{cm}^{2}$ 와 $0.38 \mathrm{~mL} / \mathrm{cm}^{2}$ 를 삽입한 전극보다 균열 된 간격이 더 큰 것으로 확인하였다. 또한, 균열 사이 거 리가 $0.38 \mathrm{~mL} / \mathrm{cm}^{2}$ 를 넣었을 때보다 $0.38 \mathrm{~mL} / \mathrm{cm}^{2}$ 의 탄소나 노튜브를 넣었을 때, 더 좁은 것으로 관찰되었다. 이를 통 하여 탄소나노튜브가 $\mathrm{Au}$ 전극의 균열을 보완해 주는 것 


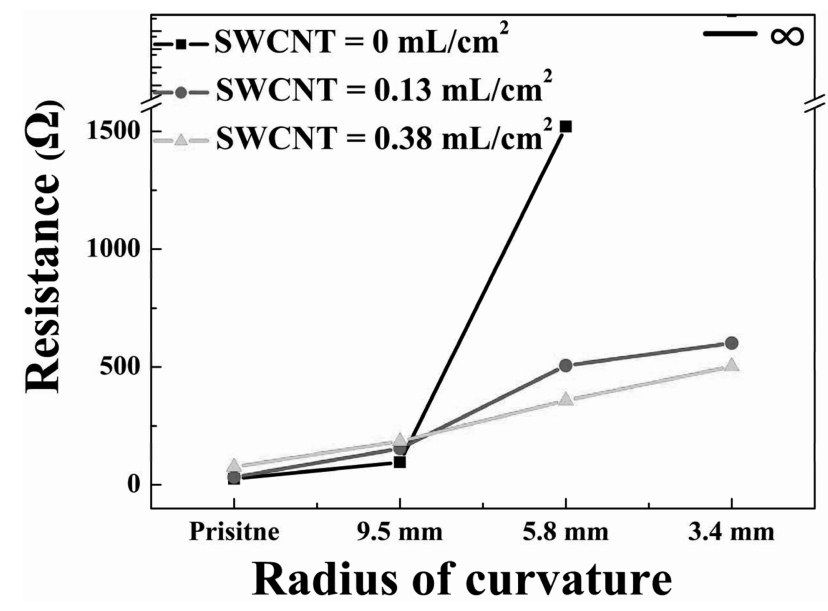

Fig. 4. The electrical resistance as a function of substrate curvature.

\section{으로 판단 할 수 있었다.}

Fig. 4는 삽입된 탄소나노튜브의 양이 $0.13,0.38 \mathrm{~mL} /$ $\mathrm{cm}^{2}$ 인 $\mathrm{Au}$ 전극의 곡률 반경이 $9.5,5.8,3.4 \mathrm{~mm}$ 으로 변 하였을 때, 각각의 저항 값을 나타낸 것이다. 탄소나노튜 브가 삽입되지 않은 $\mathrm{Au}$ 전극의 초기 저항은 $25.1 \Omega$ 으로 나타났으며, 기판에 곡률 반경이 9.5 와 $5.8 \mathrm{~mm}$ 로 변화하 였을 때, $95.1,1520 \Omega$ 으로 저항이 증가하는 것으로 나타 났다. 하지만, 곡률 반경이 $3.4 \mathrm{~mm}$ 으로 감소하였을 때, 더 이상 전기가 흐르지 않았다. 반면, 탄소나노튜브를 $\mathrm{Au}$ 전 극 사이에 $0.13 \mathrm{~mL} / \mathrm{cm}^{2}$ 의 양을 삽입한 경우, 초기저항 $31.5 \Omega$ 에서 기판의 곡률 반경을 변화시킴에 따라, 154.3 , $505.9,602 \Omega$ 로 저항이 증가하였으며, $0.38 \mathrm{~mL} / \mathrm{cm}^{2}$ 의 탄 소나노튜브를 넣은 전극의 경우 초기 저항 $76 \Omega$ 에서 곡 률 반경의 감소에 따라 각 $185,357.8,502.1 \Omega$ 으로 변화 하였다. 이는 탄소나노튜브를 삽입한 경우 탄소나노튜브 가 외부의 힘을 분산시켜주어 전극의 균열을 보완해주는 것으로 판단된다. 그리고 탄소나노튜브와 $\mathrm{Au}$ 전극의 복 합체를 제작하였을 때, 전극의 초기 저항이 증가하는 것 을 확인하였는데, 이는 탄소나노튜브와 $\mathrm{Au}$ 사이의 접촉 저항이 전체 전극 저항을 저하시킨 것으로 판단 할 수 있다. ${ }^{14)}$ 또한, 적은 양의 탄소나노튜브 보다 더 높은 밀 도의 탄소나노튜브를 전극 사이에 삽입해 주었을 때, 그 전기적 특성의 변화량이 작은 것으로 확인 할 수 있었 는데 이는 높은 밀도의 탄소나노튜브 네트워크가 전극의 균열을 보다 효과적으로 방지해 주기 때문으로 판단 된다.

Fig. 5는 전극에 tensile strain을 $0 \sim 40 \%$ 까지 가했을 때, 전극이 늘어남에 따른 $\mathrm{I}-\mathrm{V}$ 측정 결과이다. Fig. $5(\mathrm{a})$ 는 $200 \mathrm{~nm}$ 두께의 $\mathrm{Au}$ 전극이고 (b)와 (c)는 각각 탄소나노 튜브의 농도가 $0.13,0.38 \mathrm{~mL} / \mathrm{cm}^{2}$ 일 때의 전기적 특성 변화이다. 전극에 물리적 strain이 가해지지 않은 경우 저 항 값은 각 $27.6,34.5,51.7 \Omega$ 로 나타났으며, 이 결과는 위 Fig. 4.의 결과와 같이 탄소나노튜브를 증착하지 않은
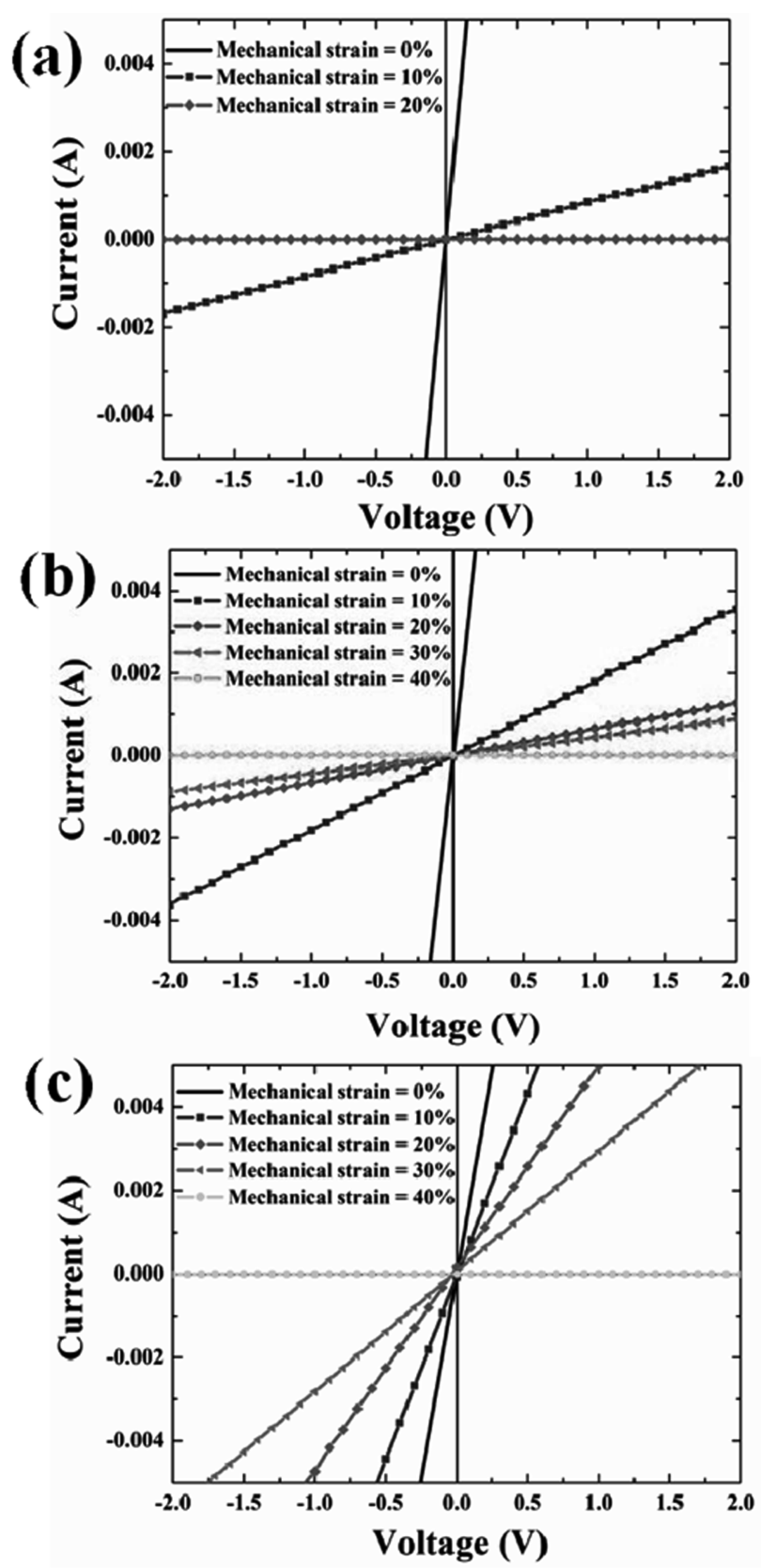

Fig. 5. The I-V characteristics of Au-SWCNT composite electrodes as a function of mechanical tensile strain; (a) without SWCNT, (b) $0.13 \mathrm{~mL} / \mathrm{cm}^{2}$ and (c) $0.38 \mathrm{~mL} / \mathrm{cm}^{2}$ of SWCNT inserted.

경우에 가장 낮게 나타났다. 또한, $\mathrm{Au}$ 로만 형성한 전극의 경우 전극을 $10 \%$ 늘였을 때 저항이 $1,189.1 \Omega$ 로 증가하 며 $20 \%$ 늘였을 경우에는 전극이 끊어져서 더 이상 전류 가 흐르지 않는 것을 확인하였다. 이에 반해 $\mathrm{Au}$ 사이에 탄 소나노튜브를 삽입한 경우 $10,20,30 \%$ 의 strain을 가해주 었을 때, $0.13 \mathrm{~mL} / \mathrm{cm}^{2}$ 인 경우 각 $555.6,1,562.5,2,272.7$ $\Omega$ 그리고 $0.38 \mathrm{~mL} / \mathrm{cm}^{2}$ 의 탄소나노튜브가 삽입된 경우 $114.3,207,347.2 \Omega$ 의 저항을 나타내었다. 또한, $40 \%$ 의 strain에서 두 전극 모두 전류가 더 이상 흐르지 않았다. 그 
리고 전극의 strain이 초기 저항에서 $10 \%$ 증가하였을 때, 전극 저항이 탄소나노튜브가 삽입되지 않은 경우, $4,200 \%$ 증가하였으며 $0.13,0.38 \mathrm{~mL} / \mathrm{cm}^{2}$ 의 양이 삽입되어 있는 경 우, 각 $1,500 \%, 120 \%$ 증가하여 탄소나노튜브의 농도가 높 을수록 strain에 따른 전극 특성 변화가 작은 것을 확인 할 수 있었다.

이를 통해 탄소나노튜브의 양의 증가는 $\mathrm{Au}$ 의 crack 현 상을 보완해 주는 것으로 확인 하였다.

\section{4. 결 론}

$\mathrm{Au}$ 전극과 탄소나노튜브 복합체를 사용하여 전극의 연 성을 향상 시키는 실험을 진행하였다. $\mathrm{PDMS}$ 기판에 $\mathrm{Au}$ $100 \mathrm{~nm}$ 를 증착한 뒤 탄소나노튜브를 spray coating 방식을 통하여 증착하였다. 그 위에 $\mathrm{Au} 100 \mathrm{~nm}$ 를 다시 증착하여 전극 사이에 탄소나노튜브를 삽입한 형태로 전극을 제작 하였다. 탄소나노튜브를 각각 $0,0.13,0.38 \mathrm{~mL} / \mathrm{cm}^{2}$ 를 삽입 한 전극의 곡률 반경을 변화시켰을 때 곡률 반경이 $3.4 \mathrm{~mm}$ 에서 전기가 통하지 않은 $\mathrm{Au}$ 전극에 반해 $\mathrm{Au}$ 전극과 탄 소나노튜브 복합체는 곡률 반경이 3.4에서 각각 $602 \Omega$, $502.1 \Omega$ 의 비교적 낮은 변화를 보였다. 또한, 전극에 tensile strain을 가해주었을 때 기존의 $\mathrm{Au}$ 전극은 $20 \%$ 에서 전류 가 흐르지 않았지만 탄소나노튜브가 삽입된 전극은 $40 \%$ 에 이르러서 끊어졌다. 또한, 탄소나노튜브의 양이 증가할 수록 저항의 증가폭이 감소하는 것을 확인하였다. 이를 통 하여 $\mathrm{Au}$ 사이에 탄소나노튜브를 삽입하여 전극을 제작하 는 경우 네트워크된 탄소나노튜브가 $\mathrm{Au}$ 의 균열을 방지해 주어 전극의 연성을 향상시킴을 확인할 수 있다.

\section{감사의}

본 연구는 LG Display의 지원으로 수행되었음.

\section{참 고 문 헌}

1. C. Lungenschmied, G. Dennler, H. Neugebauer, S. N. Sariciftci, M. Glatthaar, T. Meyer and A. Meyer, Sol. Energ. Mater. Sol. Cell., 91(5), 379 (2007).
2. W. Y. Wu, X. Zhong, W. Wang, Q. Miao and J. J. Zhu, Electrochem. Comm., 12(11), 1600 (2010).

3. G. H. Gelinck, H. E. A. Huitema, E. van Veenendaal, E. Cantatore, L. Schrijnemakers, J. B. P. H. van der Putten, T. C. T. Geuns, M. Beenhakkers, J. B. Giesbers, B. -H. Huisman, E. J. Meijer, E. M. Benito, F. J. Touwslager, A. W. Marsman, B. J. E. van Rens and D. M. de Leeuw, Nat. Mater., 3, 106 (2004).

4. J. Jeon, T. I. Lee, J. H. Choi, J. P. Kar, W. J. Choi, H. K. Baik and J. M. Myoung, Electrochem. Solid State Lett., 14(2), H76 (2011).

5. H. Huang and F. Spaepen, Acta Mater., 48, 3261 (2000).

6. S. H Ko, H. Pan, C. P. Grigoropoulos, C. K. Luscombe, J. M. J. Fréchet and D. Poulikakos, Nanotechnology, 18(34), 345202 (2007).

7. S. P. Lacour, S. Wagner, Z. Huang and Z. Suo, Appl. Phys. Lett., 82(15), 2404 (2003).

8. J. Jeon, J. H. Choi, K. J. Moon, T. I. Lee, H. Moon, H. Y. Kim and J. M. Myoung, Kor. J. Mater. Res. 20(2), 51 (2010).

9. K. S. Kim, Y. Zhao, H. Jang, S. Y. Lee, J. M. Kim, K. S. Kim, J. -H. Ahn, P. Kim, J. -Y. Choi and Byung Hee Hong, Nature, 457, 706 (2009).

10. S. De, P. E. Lyons, S. Sorel, E. M. Doherty, P. J. King, W. J. Blau, P. N. Nirmalraj, J. J. Boland, V. Scardaci, J. Joimel and J. N. Coleman, ACS Nano, 3(3), 714 (2009).

11. S. H. Ng, J. Wang, Z. P. Guo, J. Chen, G. X. Wang and H. K. Liu, Electrochim. Acta, 51(1), 23 (2005).

12. M. J. Biercuk, M. C. Llaguno, M. Radosavljevic, J. K. Hyun, A. T. Johnson and J. E. Fischer, Appl. Phys. Lett., 80(15), 2767 (2002).

13. M. F. Islam, E. Rojas, D. M. Bergey, A. T. Johnson and A. G. Yodh, Nano Letters, 3(2), 269 (2003).

14. S. C. Lim, J. H. Jang, D. J. Bae, G. H. Han, S. Lee, I. S. Yeo and Y. H. Lee, Appl. Phys. Lett., 95(26), 264103 (2009). 